Ethiopian Journal of Environmental Studies \& Management 10(2): 176 - 185, 2017.

ISSN:1998-0507

Submitted: August 08, 2016

doi: http://dx.doi.org/10.4314/ejesm.v10i2.4

Accepted: February 27, 2017

\title{
RIVER USE, CONSERVATION AND MANAGEMENT AMONG RIVERINE COMMUNITIES IN SOUTHEASTERN NIGERIA
}

\author{
UDECHUKWU C.E., CHUKWU, P.E. AND *AMAECHINA, E.C. \\ Department of Agric Economics, University of Nigeria, Nsukka
}

\begin{abstract}
Water holds important and diverse benefits for society. It is essential for economic and social development and is important for maintaining the livelihoods of people both in rural and urban areas. The connection between people and water dates back to the earliest origins of life and show the cultural values and social differences that are present in societies. With growing water scarcity, competition for the resource, climate change impacts and pollution, integrated water resource management has been increasingly enlisted as a way to better manage the resource. However the problem remains that many water resource planning and management regimes do not capture the views of the myriad of stakeholders and the many benefits of ecological services. This paper examines river use, conservation and management among riverine communities in South Eastern Nigeria using descriptive statistics on primary data collected from a survey of rural households along two rivers in southeastern Nigeria., Although more than $60 \%$ of the respondents in the Local Government areas sampled indicated uses of water for various domestic ends and that other uses like recreation, industry and ecosystem services were indicated and that they are able to attach economic values to these roles, the communities lack the capacity for resource management and conservation. It proposes a strong need for public enlightenment and empowerment for effective water resource management.
\end{abstract}

Key Words: Water use, Conservation, Livelihoods, Participation, Common property

\section{Introduction}

Water is a vital input to the livelihood activities of people (Poverty Environment Partnership (PEP) (2006). Water is important for everyday activities of drinking, cooking, bathing, washing clothes and watering gardens. It secures livelihoods for farmers who irrigate their crops and for fisher folk who engage in fishery activities. Water is also a good source of recreation for swimming, boating and just sightseeing. A good deal of transportation is carried out in Nigeria's inland water ways. Apart from other industrial uses, water is also important for hydroelectric power generation in Nigeria and provides ecosystem services.

Nigeria is endowed with abundant water resources. Nigeria's water resources potential is estimated to be 250,000 million cubic meters (MCM) of which 190,000 MCM is surface water, while the remaining is groundwater 
(FAO Aquastat, 2003). Yet, Nigeria is one of the countries in Africa projected to go under water stress by 2025 , as high demand for fresh water and competition between sectoral uses and communities are driving unsustainable practices (UNEP, 2002). With increasing changes in global climatic conditions and population, this situation is being heightened. For many people - especially in rural areas, water is considered a free resource that comes from rivers, rain, and underground aquifers. But water increasingly is becoming a scarce resource needing to be managed sustainably. The World water council, Third World Water Forum and Global Water Partnership (2003) recognized that sustainable growth and poverty reduction cannot take place if water resources are not adequately managed. According to PEP (2006), Water management is also important for sustainable ecosystems like reefs, wetlands and mangroves. Actions that are directed towards promoting sustainable patterns of exploitation are needed. This requires creation of conducive conditions for sustainable ecosystem management within river basins.

During the last few decades, experts worldwide have studied and shared knowledge to reach an understanding about the way water resources should be managed, and this process led the way towards "Integrated Water Resource Management" (Cap-Net, LA-Wetnet and European Union). The Global Water Partnership defines Integrated water resource management as a process which " promotes the coordinated development and management of water, land and related resources in order to maximize the resultant economic and social welfare in an equitable manner without compromising the sustainability of vital eco-systems" (UNDP Water Governance Facility, Water Integrity Network, CapNet and Waternet (2011). Other definitions of IWRM abound but all contain the principles of equity, efficiency and environmental sustainability.

In Nigeria, many agencies in the water sector and at all levels of government perform similar functions with different agenda. As a result, water development policy issues and actions are fragmented (Irokalibe, 2008). Akanmu et al. (2007) identified the River Basin Development Authorities as the main agency responsible for integrated water resource management. As such, they are responsible for planning and creating the conducive environment for integrated conservation, development and management of water in its different uses.
According
to
FAO
(1993)

"Participation" means to take part in or to be involved in an activity. Many aspects of social life consist of people coming together for one cause or the other. Public and private sector projects and programmes have increasingly sought people's participation as a means to achieving their objectives. All over the world, nations that once championed more government led initiatives in natural resource management are now advocating and adopting policies that create more opportunities for participation by stakeholders, leaving the government agencies to concentrate on management of water at the main system level.

In the case of surface water systems like rivers and lakes, they can be characterized as a public good. Ellis (1992) noted the case for irrigation but it can be extended for surface water 
resource. It would cost too much in practice to regulate the amount of water consumed by the individual, and it is often not possible to prevent people at the periphery of surface waters from making use of the water. The attention given to participation in the water resource sector is as a result of concerns for sustainability of the resource and services. The question to ask in considering participation is "who is best suited to carry out which management functions". When this question is addressed objectively the result involves a greater degree of user participation than is typically observed at present. The public have been excluded from water resource management decisions that they can and should from an efficiency perspective be involved in (Groenfeldt, 2000).

Most of all, however, people's participation provides a basis for the sustainability of development and environment initiatives. Prescribing and encouraging the participation of individuals and institutions that would be affected by decisions about water resources management produces a number of benefits. Yet Nigeria's water resource management system at present exhibits a tokenistic inclusiveness for stakeholders. This paper examines water resource use among rural communities along two rivers in the southeastern part of Nigeria. The usage of water by the household was ascertained, as well as gender issues in water use and management. The economic value the households attached to the benefits derived from the resource was also ascertained.

\section{Methodology \\ Study Area}

The study area is South-eastern Nigeria riverine communities. South eastern Nigeria is comprised of Abia, Imo, Ebonyi, Enugu and Anambra states. The zone is within the rainforest agroecological belt of Nigeria, with its major features being high humidity and temperature and substantial amount of rainfall that occur within most months of the year (Lekwa et al., 2001). The annual average rainfall is $1730 \mathrm{~mm}$ (Asadu, 2014). The region is located within longitudes $5^{\circ} 30^{\prime}$ to $9^{\circ} 30^{\prime}$ East and latitudes $4^{\circ} 30^{\prime}$ to $7^{\circ} 00^{\prime}$ North. Some of the states are bounded by two major riversRiver Niger and Cross river . This paper is based on a study of riverine communities along the Eastern course of the river Niger, and also of the Cross river. Specifically, the River Cross tributary (Oziza River) in Ebonyi state, and the South eastern Nigeria part of the River Niger in Anambra State formed the basis for this study. 


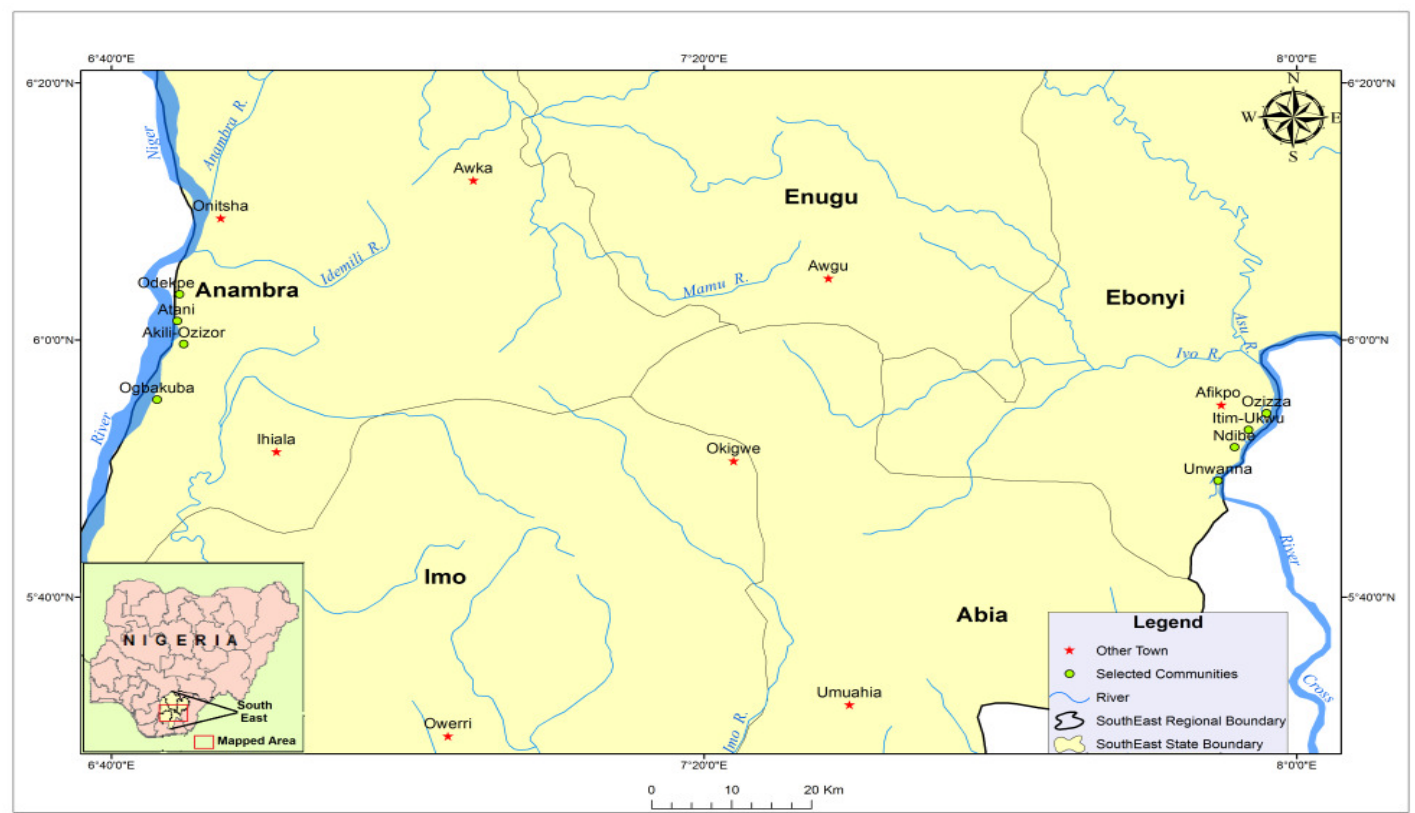

Fig. 1: Riverine Parts of South eastern Nigeria

\section{Sample and Data Collection}

This study focused on River water resources in South Eastern Nigeria. In Ebonyi State, four communities out of the six communities that make up Afikpo North Local Government Area were selected based on proximity to the river. In Anambra state, Ogbaru Local Government Area was purposively selected for proximity to river Niger. Four communities were also purposively selected. A total of one hundred and twenty households were randomly selected, sixty each for each of the two rivers. Data was collected through administration of questionnaire, key informant interview and personal observation. Information obtained include the socioeconomic characteristics of the respondents, the various usages of the river water, conservation and management practices in place, and total economic value of the benefits from the water from the households perspectives. Data collected was analyzed using descriptive statistics.

\section{Concept of Total Economic Value of Water}

The economic value attached to a resource can be deduced from its impact on social welfare. An aggregation of utility by individuals in a society gives a picture of social welfare. The utility to individuals is observable from their preferences, which is the way they internally value the goods (Cap-Net, 2008). These preferences are expressed by the amount they are willing to pay for goods and services. Economic value of water resources are usually expressed in monetary terms, taking into cognizance form, time and place issues associated with the resource (Young, 2005). A key step in water resource valuation is to identify the functions it performs by establishing the connections between the structures and processes of water resources and the goods and services it provides that are of value to society (Young, 1996).

Figuring out how individuals use water is important in establishing the total economic value of water. This is 
based on two categories: Use values and Non-Use values (Young, 1996; Barbier,
1994). The table below summarizes the total Economic value of water.

Table 1: Components of the total economic value of water resources

\begin{tabular}{lll}
\hline & Use value & $\begin{array}{l}\text { Direct use - Drinking, } \\
\text { agriculture etc }\end{array}$ \\
Total & & Indirect use- Recreation \\
Economic & & and tourism \\
value & & Ecosystem Functions \\
& Non- use & $\begin{array}{l}\text { Existence value } \\
\text { Bequest value } \\
\text { value }\end{array}$ \\
& & Future option Value \\
\hline
\end{tabular}

Source: FAO (2004)

\section{Results and Findings \\ Uses of Water}

Uses of water were ascertained from the respondents and presented below:

Agricultural use of water: majority of the respondents used water for various forms of agriculture. Crop production (83.3\%, $\mathrm{N}=50)$ Ogbaru LGA and (93.3\%, $\mathrm{N}=56)$ Afikpo LGA; Livestock production $(58.3 \%, \mathrm{~N}=35)$ Ogbaru, and $(78.3 \%, \mathrm{~N}=47)$ Afikpo. Irrigation (55\%, $\mathrm{N}=33)$ Ogbaru, and $(66.7 \%, \mathrm{~N}=40)$ Afikpo.

Aquaculture: Fish rearing in river (35\% $\mathrm{N}=21)$ ogbaru, (68.3\%, $\mathrm{N}=41)$ Afikpo. Fish rearing in manmade ponds near the river $(26.7 \%, \mathrm{~N}=16)$ Ogbaru and (43.3\%, N = 26) Afikpo. Fish harvesting from river $(48.3 \%, \quad \mathrm{~N}=29)$ Ogbaru $(65.0 \%, \mathrm{~N}=39)$ Afikpo.

Domestic Purposes: The major domestic uses were - Drinking $(81.7 \%, \mathrm{~N}=49)$ ogbaru, and $(63.3 \%, \mathrm{~N}=38)$ Afikpo. Cooking (90\%, $\mathrm{N}=54)$ Ogbaru and $(100 \%, \mathrm{~N}=60)$ Afikpo; Washing clothes $(96.7 \%, \mathrm{~N}=58)$ Ogbaru and $(100 \%, \mathrm{~N}=$ $60)$ Afikpo. Bathing $(95 \%, \mathrm{~N}=57)$ Ogbaru and $(100 \%, \mathrm{~N}=60)$ Afikpo. Gardening $(66.7 \%, \mathrm{~N}=40)$ Ogbaru and $(100 \%, \mathrm{~N}=60)$ Afikpo.

Recreational Purposes: The recreational purposes identified include - Swimming
$(88.3 \%, \mathrm{~N}=53)$ Ogbaru and $(91.7 \%, \mathrm{~N}=$ 55) Afikpo, Boating trips $(81.7 \%, \mathrm{~N}=$ 49), Ogbaru and (68.3\%, $\mathrm{N}=41$ ) Afikpo, Nature watch of water or sightseeing $(56.7 \%, \mathrm{~N}=34)$ Ogbaru, and $(83.3 \%, \mathrm{~N}$ = 50) Afikpo. In Ogbaru, religious uses were also ascertained. Baptism $(38.3 \%, \mathrm{~N}$ $=23)$, Sacrifices to the gods $(38.3 \%, \mathrm{~N}=$ 23).

Industrial Uses: Respondents were questioned on their awareness of presence of industries that make use of their river water and their responses follow: Hydropower generation firm (0\%) Ogbaru, $(67 \%, \mathrm{~N}=4)$ Afikpo. Use by factories in community $(31.7 \%, \mathrm{~N}=$ 19) Ogbaru and (26.7\% $\mathrm{N}=16)$ Afikpo.

Ecosystem Uses: The respondents' awareness of ecosystem functions of the river were ascertained and the response $(61.66 \%, \mathrm{~N}=37)$ Ogbaru and $(18.3 \%, \mathrm{~N}$ = 11) Afikpo were obtained. The above shows that the Stretch of River Niger in Ogbaru LGA and that of Cross River in Afikpo LGA is very useful to the communities that lie along the two rivers. It is alarming to note that they drink the water from the rivers given that it is not treated. 
Community Rules and Sanctions for River Water Management

The existence of rules and sanctions governing their interactions and usage of water in both Ogbaru LGA and Afikpo LGA were ascertained and presented below.

The rules and sanctions governing water use in the communities were elicited and presented below.

Table 2: Rules and sanctions by the communities

\begin{tabular}{|c|c|c|c|}
\hline & Category & Frequency & $\begin{array}{l}\text { Percentage } \\
\%\end{array}$ \\
\hline \multirow{3}{*}{$\begin{array}{l}\text { Existence of } \\
\text { rules and } \\
\text { regulation } \\
\text { Source of Rules }\end{array}$} & Yes & 45 & 37.5 \\
\hline & No & 75 & 62.5 \\
\hline & Forefathers & 31 & 25.8 \\
\hline \multirow{7}{*}{ Source of Rules } & Traditional & 8 & 6.66 \\
\hline & cabinet & 8 & 6.66 \\
\hline & Entire community & 1 & 0.83 \\
\hline & Men only & 2 & 1.66 \\
\hline & Women only & 2 & 1.66 \\
\hline & Government & 67 & 55.83 \\
\hline & Not sure & & \\
\hline \multirow{3}{*}{$\begin{array}{l}\text { Sanctions } \\
\text { defaulters }\end{array}$} & Yes & 36 & 30 \\
\hline & No & 82 & 68.33 \\
\hline & Not sure & 2 & 1.66 \\
\hline
\end{tabular}

The table shows that there is a weak effort by the communities to develop and enforce rules governing the use of water. It can be seen for existence of rules that only $37.5 \%$ were aware. Also majority of the respondents $55.83 \%$ were not sure who made the rules. Majority also stated there are no sanctions for defaulters. This is probably because of the nature of water being a common property resource as discussed. It could also stem from their perception of the ever abundance of water. This supports the view that there is need to change the way rivers are currently managed to a more sustainable one that promotes harmonious coexistence between people and nature (Swiderska et al., 2010). This calls for strong action of raising awareness of community on the roles they can play in conserving and managing the water resource. 


\section{Gender Issues in River Use, Conservation and Management}

Table 3: Distribution of respondents based on gender issues in river use, conservation and management

\begin{tabular}{llll}
\hline Attribute & Category & Frequency & Percentage \\
$\begin{array}{l}\text { Gender responsible for } \\
\text { river conservation and }\end{array}$ & Adult men & 78 & 65 \\
management & Youth women & 16 & 13.33 \\
& Children & 12 & 10 \\
& No response & 4 & 3.33 \\
Gender responsible for & Adult men & 10 & 8.33 \\
fetching water in your & Adult women & 2 & 1.66 \\
household & Youth & 14 & 11.66 \\
& Children & 79 & 18.33 \\
& No response & 3 & 65.83 \\
Gender that benefits & Adult men & 27 & 2.5 \\
most from the water & Adult women & 51 & 22.5 \\
resource & Youth & 30 & 42.5 \\
& Children & 3 & 25 \\
& No response & 9 & 2.5 \\
Gender that negatively & Adult men & 16 & 7.5 \\
impacts on river & Adult women & 39 & 13.33 \\
& Youth & 6 & 32.5 \\
& Children & 3 & 5 \\
& No response & 54 & 2.5 \\
& & & 45 \\
\hline
\end{tabular}

The table shows that for fetching water the responsibility lied with youth and children. The gender that is responsible for river conservation is the adult male. As per the gender that benefits most from the rivers, a greater number of the respondents $(51$ i.e $42,5 \%)$ stated that it is the adult female. It could also be based on the view by CapNet/GWA (2006) that women are first to be affected in times of water shortage because their livelihoods revolves around it. This could be because they are the members of the household responsible for providing care in the household. The women are viewed as the gender that most negatively impacts on the water.
This contradicts Cap-Net GWA (2006) position that powerful groups usually men do the most harm to the environment as they have the capacity to undertake large scale and systematic exploitation of the resource.

\section{Total Economic Value of Water}

Although freshwater provides numerous benefits to society, the market is not able to assess all the values associated with the resource. Non market valuation techniques can be used to assess the value people place on goods and services that are not bought or sold in the market (TEEB, 2010; Day and Mourato, 2002; Mitchell and Carson, 1981). 
According to TEEB (2010), the Total Economic Value (TEV) framework is the dominant framework for analysis of monetized benefits from ecosystems. TEEB (2010) further stated that the strong point of the TEV is that all benefits that people receive from nature and even the intrinsic value of nature can be captured by one of the sub-categories.

Table 4: Distribution of respondents according to total economic value of water

\begin{tabular}{|c|c|c|c|}
\hline \multirow[t]{2}{*}{ Use/Benefit } & \multicolumn{3}{|c|}{ Average amount( $₫)$ per year } \\
\hline & Afikpo (Oziza River) & $\begin{array}{l}\text { Ogbaru } \\
\text { River) }\end{array}$ & (Niger \\
\hline $\begin{array}{l}\text { Consumptive use } \\
\text { (cooking, drinking, } \\
\text { washing, gardening) }\end{array}$ & $22,154.00$ & 147,170 & \\
\hline Recreation & $1,650.42$ & 21,703 & \\
\hline Ecosystem function & $4,658.17$ & 20,572 & \\
\hline $\begin{array}{l}\text { Non use value (existence, } \\
\text { bequest, philanthropic }\end{array}$ & 8742.51 & 33,232 & \\
\hline
\end{tabular}

The table shows the respondents' economic value attached to the benefits derivable from the water resource. It can be seen that they place a higher value on the consumptive use of water as expected. Surprisingly they also place a high importance on non use values of the river. For them to attach such economic value to the water resource shows that the resource is important to their livelihoods. A similar study by Barbier et al. (1997) in the Hadejia-Nguru wetlands of Northern Nigeria, using a partial valuation approach, provided key direct use values the wetland provided to local populations in the area of crop production, fishing and fuelwood. The study showed that agricultural, fishing and fuelwood benefits were valued from N253- N381 per hectare. Given the values indicated by the respondents above, the communities would be inclined to take some responsibility for river conservation and management. There is need to tap into this and raise their awareness of how some of their activities negatively impacts on water, and of how they can, as people closest to the resource, contribute to management.

\section{Conclusion}

This study shows that water from the rivers is very central to the livelihoods of the communities along the two rivers. However the resource is poorly managed by the communities. Sustainable growth and poverty reduction requires that water resources be managed effectively (PEP, 2006). Ecosystems can only be preserved by ensuring continuity in water flows and maintaining good water quality. This can only happen when all stakeholders participate in management. The communities around the river resource are the primary stakeholders. They should be empowered to actively contribute to resource conservation and management.

\section{References}

Akanmu, J.O., Eluwa, O. and Ekpo, I. (2007). Chronicles of river basin management in Nigeria. www.dsi.gov.tr/english/congress20 07/chapter1/09.pdf 
Babier, E.B. (1994). Valuing environmental functions: Tropical wetlands. Land Economics, 70 (2): $155-173$.

Barbier, E.B., Acreman, M. and Knowler, D. (1997). Economic Valuation of Wetlands: a Guide for Policy makers and Planners. Ramser Convention Bureau, Switzerland

Cap-Net UNDP. (2008). Economics in sustainable water resource management. Cap-Net Delft

CAP-NET, GWA. (2006). Why gender matters: A tutorial for water managers. Multimedia $\mathrm{CD}$ and booklet. International network for capacity building in integrated water management. Delft.

Cap-Net, LA-Wetnet and European Union. (2010). Streams of law: A training manual and users guide on water legislation and legal reform for integrated water resource management.

Day, B. and Mourato, S. (2002). Valuing River water Quality in China. In D, Pearce, C.pearce \& C.Palmer (Eds). Valuing the environment in Developing Countries: Case Studies. Edward Elgar, Massachusetts USA.

Ellis, F. (1992). Agricultural policies in developing countries. Cambridge University Press Cambridge.

FAO. (1993). Enhancing people's participation in the tropical forests action programme FAO Bangkok.

FAO AQUASTAT. (2005). FAO Information system on water and agriculture.http://www.fao.org/nr/w ater/aquastat/countries_regions/NG A/index.stm

Global Water Partnership. (1999). The Dublin principles for water as reflected in a comparative assessment of institutional and legal arrangements for integrated water resource management. www.gwptoolbox.org/images/storie s/gwplibrary/background/tac_3_english.pdf

Groenfeldt, D. (2000). Introduction: A Global Consensus on Participatory Irrigation Management. In Groenfeldt, D. and Svendsen, M. (eds.) (2000). Case studies in participatory irrigation management WBI learning resources series, World Bank Institute Washington D.C. USA.

Hinrichsen, D., Robey, B., and Upadhyay, U.D. (1998). Solutions for a Water-short World. Population Reports Series M No 14 Johns Hopkins School of Public Health

Irokalibe, I.J. (2008). Water management in Federal and Federal type Countries: Nigerian perspectives. Ahmadu Bello University Zaria, Nigeria.

Lekwa, M.U., Akamigbo, F.O.R. and Lekwa, O. (2001). A detailed soil survey of the soils of Igwu River flood plain in Arochukwu LGA Abia state of Nigeria for Swamp rice Production. Proceedings of $27^{\text {th }}$ Annual Conference of Soil Science Society of Nigeria held at the University of Calabar, Nigeria

Mitchell, R.C. and Carson, R.T. (1989). Using Surveys to Value Public Goods: the Contingent Valuation Method, Washington, Resources for the Future. $463 \mathrm{p}$

Poverty Environment Partnership (PEP). (2006). Linking poverty reduction and water management. UNDP

Sudevi, B. and Lokesh, K.S. (2014). Critical Analysis of Economic 
Tools available for Assessing River water Quality. International Journal of Water Resources and Environmental Engineering, 6(11): 287- 294.

Swiderska, K.D., Roe, L., Siegele, and Grieg-Gran, M. (2010). The governance of nature and the nature of governance: Policy that works for biodiversity and livelihoods. IIED.

The Economics of Ecosystem and Biodiversity (TEEB) (2010). The Economics of Ecosystem and Biodiversity for Local and regional Policy Makers.

Tietenberg, T. (1992). Environmental and natural resource economics. Haper Collins publishers inc. New York.

UNDP (2011). Water Governance Facility, Water Integrity Network, Cap-Net and Waternet. Training manual on water iIntegrity. UNDP WGF at SIWI 2011

United Nations Environment Program (2002). Africa Environment Outlook: Past, Present and Future Perspectives UNEP Kenya Nairobi. World Water Council. (2003). Third world water forum and global water partnership. Financing water for all.

Young, R.A. (1996). Measuring economic benefits for water investments and policies. World bank technical paper No.338.

Young, R.A. (2005). Determining the economic value of water Concepts and methods. www.rff.org/rff/IRFF_Press/Custo mBookPages/Loader.cfm?url=/com monspot/security/getfile.cfMicrosoft. 